\author{
Kajetan Jagodziński \\ (Gniezno)
}

\title{
ZNACZENIE ALMANACHU 1C Z KODEKSU DREZDEŃSKIEGO DLA ROZWOJU EPIGRAFIKI MAJAŃSKIEJ
}

\section{Abstract}

This papers seeks to demonstrate the tremendous importance of the usually omitted first page of the Dresden Codex for the ongoing process of deciphering Mayan script. As an example, one could quote the recently identified Mayan term denoting a loincloth (Span. braguero, taparrabo) in the almanac 1c, which may be found on the page in question. Furthermore, the author critically discusses all possible forms in which the word can have been written, as it still defies being deciphered completely.

\section{Key words}

Dresden Codex, braguero, Mezoamerican codices, Mayan script, post-classical period 


\section{WSTĘP}

Kodeks Drezdeński już od ponad dwóch stuleci nieustannie wzbudza nie tylko zainteresowanie naukowców, ale i zaciekawienie amatorów. Manuskrypt ten to jedno z podstawowych źródeł w badaniach nad dawną kulturą Majów, która obejmuje zasięgiem dzisiejszy południowo-wschodni Meksyk, Belize, Gwatemalę oraz zachodnią część Salwadoru i Hondurasu. Wieloletnie badania Kodeksu przyczyniły się do lepszego zrozumienia tej prekolumbijskiej cywilizacji. Rozliczne prace poświęcone wspomnianemu dokumentowi obejmują szerokie spektrum zagadnień: począwszy od religii, poprzez lingwistykę i ikonografię, a skończywszy na astronomii. Dotychczas uwaga naukowców skupiona była na analizie dobrze zachowanych stron Kodeksu. $\mathrm{Z}$ tego powodu pierwszą stronę manuskryptu, której stan zachowania można określić jako fragmentaryczny i bardzo nieczytelny, traktowano powierzchownie. Celem niniejszego artykułu jest wskazanie, jak ważną rolę w trwającym procesie odszyfrowywania pisma glificznego dawnych Majów może odegrać krytyczna analiza pierwszej strony kodeksu, a w szczególności zamieszczony w jej dolnej części almanach (1c).

\section{HISTORIA MANUSKRYPTU}

Z całego dorobku kultury piśmienniczej dawnych Majów zachowało się ponad 5000 tekstów ${ }^{1}$, w tym jedynie cztery malowane księgi, znane jako Kodeks Drezdeński, Madrycki, Paryski i Grolier. Współczesne określenia trzech pierwszych kodeksów nawiązują do nazw miast, w których księgi są obecnie przechowywane. Czwarty kodeks otrzymał nazwę od Klubu Grolier w Nowym Jorku, najstarszego stowarzyszenia bibliofilskiego w Ameryce Północnej, w którego siedzibie po raz pierwszy publicznie wystawiono manuskrypt $\mathrm{w}$ roku $1971^{2}$. Tak niewielka liczba zachowanych kodeksów majańskich jest

\footnotetext{
${ }^{1}$ Ch. Helmke, H. Kettunen, Wprowadzenie do hieroglifów Majów [online]. Wayeb [dostęp: 2016-12-20]. Dostępny w Internecie: <http://www.wayeb.org/download/resources/wh2009polish.pdf>.

${ }^{2}$ Kodeks Grolier wzbudzał przez dłuższy czas kontrowersje wśród naukowców, z których część uważała, że jest to współczesny falsyfikat. Pod koniec roku 2016 grupa amerykańskich naukowców opublikowała artykuł w książce „Maya Archaeology 3”, w którym zebrała argumenty przemawiające za jego autentycznością. Część wątpliwości brała się z faktu, że został on odnaleziony w niejasnych okolicznościach i sprzedany prywatnemu kolekcjonerowi meksykańskiemu, Josué Sáenzowi. Co więcej, ów kodeks jest zupełnie odmienny stylistycznie od trzech pozostałych. Uznanie jego autentyczności wiąże się z przyznaniem mu miana najstarszej książki obu Ameryk. Obecnie jako jedyny z kodeksów majańskich jest przechowywany w stolicy Meksyku.
} 
spowodowana kilkoma czynnikami. Przede wszystkim klimat tropikalny destruktywnie wpływa na papier amatl, który produkowany jest z kory figowca ${ }^{3}$. Potwierdzeniem takiego stanu rzeczy są zbutwiałe resztki kodeksów, pochodzące $\mathrm{z}$ okresu klasycznego (III-IX w. n.e.) i odnalezione w grobowcach na terenie takich stanowisk archeologicznych, jak Uaxactún, Altun Ha czy Copan 4 .

Na podstawie źródeł kolonialnych można wywnioskować, że ten sposób zapisywania i przechowywania informacji był bardzo rozpowszechniony wśród Majów. Wyjaśnia to zaciekłość, z jaką Hiszpanie niszczyli malowane księgi tubylców, co stanowiło ważny element walki z idolatrią. Jeszcze w XVIII w. na terenie półwyspu Jukatan odnotowywano przypadki konfiskowania kodeksów zapisanych glifami majańskimi ${ }^{5}$. Upadek postklasycznej kultury Majów i rozpad dawnych struktur społecznych, a także hiszpańska polityka ewangelizacji autochtonów przyczyniły się w znacznym stopniu do zaniku tej niegdyś rozpowszechnionej formy pisania, jaką było sporządzanie kodeksów.

Spośród zachowanych majańskich manuskryptów Kodeks Drezdeński stanowi szczytowe osiągnięcie piśmiennictwa dawnych Majów. Nie ma ono sobie równych pod względem kaligrafii i subtelnego sposobu komponowania przedstawień ikonograficznych. Zazwyczaj uczeni datują go na XIII w. (lata 1200-1250), na co wskazywałyby zawarte w nim między innymi informacje astronomiczne ${ }^{6}$. Część badaczy uważa jednak, że data ostatniej kompilacji manuskryptu może być znacznie późniejsza i przypadać nawet na XVI w. ${ }^{7}$ Debata wśród naukowców również dotyczy miejsca powstania kodeksu. Najbardziej rozpowszechniona koncepcja wskazuje okolice Chichen Itza jako

\footnotetext{
${ }^{3}$ S. Salgado Ruelas, Análisis semiótico de la forma arbórea en el Códice de Dresde, México 2001, s. 47.

${ }^{4}$ Ibidem, s. 46. Warto się zapoznać z artykułem „Multispectral imaging of an Early Classic Maya codex fragment from Uaxactun, Guatemala" Nicolasa Cartera i Jeffreya Dobereinera, w którym naukowcy przebadali pozostałości kodeksu znalezionego w grobie A6 w Uaxactún. Dzięki zastosowaniu najnowszych technologii stwierdzono istnienie dwóch warstw stiuku, świądczących o ponownym zapisywaniu na tej samej karcie nowych tekstów.

${ }^{5}$ J.F. Chuchiak IV, Writing as Resistance: Maya Graphic Pluralism and Indigenous Elite Strategies for Survival in Colonial Yucatan, 1550-1750, Ethnohistory 57, 2010, s. 87-116.

${ }^{6}$ E. Thompson, Códice de Dresde. Un comentario al Códice de Dresde. Libro de jeroglifos mayas, México 1988, s. 41; H.M. Bricker, V. Bricker, A method for cross-dating almanacs with tables in the Dresden Codex, [w:] A.F. Aveni (red.), The Sky in Mayan Literature, New York 1992, s. $46-87$.

${ }^{7}$ Ibidem, s. 83; A. Lacadena, Evolución formal de las grafías escriturarias mayas: Implicaciones históricas y culturales, Madrid 1995, s. 302-313.
} 
potencjalny rejon, gdzie sporządzono dokument ${ }^{8}$. Niektórzy badacze podają również inne możliwe lokalizacje, takie jak Mayapan, Santa Rita Corozal czy Tulum 9 .

Niewiele wiadomo o losach Kodeksu Drezdeńskiego aż do momentu ujawnienia jego istnienia przez Johanna Götze. Nie jest też znana droga, jaką manuskrypt dotarł do Europy. Niewykluczone, że wraz z innymi cennymi przedmiotami został wysłany na dwór Karola V w roku 1520 przez Hernana Cortesa jako dar ukazujący bogactwo nowo podbitych ziem ${ }^{10}$. Pierwsza pewna informacja o Kodeksie Drezdeńskim pochodzi z roku 1739, kiedy to Johann Götze, dyrektor biblioteki królewskiej w Dreźnie oraz dawny kapelan króla Polski Augusta III, zakupił go od prywatnej osoby w Wiedniu podczas swojej podróży do Włoch ${ }^{11}$. W roku 1740 Kodeks Drezdeński został wpisany do inwentarza biblioteki w stolicy Saksonii ${ }^{12}$. Jedno z pierwszych odniesień do faktu istnienia tego dokumentu znajduje się w dziele zatytułowanym „Darstellung und Geschichte des Geschmacks der vorzüglichsten Völker” autorstwa barona Josepha Friedricha von Racknitza. Publikacja prezentowała różne style architektoniczne, które pojawiły się pod koniec XVIII w. Rycina oznaczona numerem 34 przedstawiała wystrój wnętrza w stylu meksykańskim, w którym niektóre elementy dekoracyjne zostały zaczerpnięte $\mathrm{z}$ ikonografii omawianego manuskryptu ${ }^{13}$.

W ciągu ponad 250 lat od momentu zakupienia manuskryptu przez Johanna Götze, Kodeks Drezdeński był wielokrotnie publikowany przez różne wydawnictwa na całym świecie ${ }^{14}$. Jego historia edytorska zaczęła się w roku 1810, gdy niemiecki podróżnik Aleksander von Humboldt umieścił w swojej książce „Vues de Cordilleres” reprodukcje kilku stron tego majańskiego manuskryptu, które wykonał Aimè Bonpland. Przedstawiały one wyłącznie tablice astronomiczne dotyczące planety Wenus i zaćmień Księżyca.

\footnotetext{
${ }^{8}$ E. Thompson, Códice de Dresde, s. 269.

${ }^{9}$ M. Paxton, Codex Dresden: Late Postclassic Ceramic Depictions and the Problems of Provenience and Date of Painting, [w:] M.G. Robertson, V.M. Fields (red.), Sixth Palenque Round Table, 1986, Oklahoma 1991, s. 303-308; S. Salgado Ruelas, Análisis semiótico..., s. 48.

${ }^{10} \mathrm{Ch}$. Hernandez, G. Vail, Recreating Primordial Time. Foundation Rituals and Mythology in the Postclassic Maya Codices, Boulder 2013, s. 2.

${ }^{11}$ F. Anders, H. Deckert, Codex Dresdensis, Graz 1975, s. 13.

${ }^{12}$ S. Salgado Ruelas, Análisis semiótico, s. 51; E. Thompson, Códice de Dresde, s. 44; N. Grube, Der Dresdner Maya-Kalender: Der vollständige Codex, Freiburg-Bassel-Wien 2012, s. 10-11.

${ }^{13}$ M. Coe, Una referencia antigua al Códice de Dresde, Estudios de Cultura Maya 3, 1963, s. 37-40.

${ }^{14}$ Szczegółowe zestawienie wydań Kodeksu Drezdeńskiego, wraz z szerszym omówieniem, zawiera książka S. Salgado Ruelas „Análisis semiótico” oraz wprowadzenie Thomasa A. Lee do edycji „Los Códices Mayas”.
} 
Dopiero w wielotomowym dziele „Antiquities of Mexico” autorstwa Edwarda Kinga, hrabiego Kingsborough, Kodeks Drezdeński został opublikowany po raz pierwszy $\mathrm{w}$ całości. Ukazał się on $\mathrm{w}$ trzecim tomie tej monumentalnej publikacji (1830-1831), razem z kodeksami ze środkowego Meksyku, takimi jak Borgia czy Fejervary-Mayer. Autorem tych rycin był włoski artysta Agostino Aglio, który stosunkowo wiernie odwzorował warstwę ikonograficzną majańskiego manuskryptu, przykładając niestety znacznie mniej uwagi i staranności w przedstawianiu glifów, czyli tekstu ${ }^{15}$.

Ernst Förstemann, bibliotekarz w Królewskiej Bibliotece w Dreźnie i jednocześnie wielce zasłużony majanista, był odpowiedzialny za kolejne dwa wydania Kodeksu Drezdeńskiego (w roku 1880 w Lipsku, a następne w Dreźnie w 1892 roku). Do ich wykonania użyto techniki chromolitografii ${ }^{16}$, dzięki której można było dokładnie i wiernie jak na ówczesne standardy oddać różne detale manuskryptu oraz jego kolorystykę. Zasadniczą cechą odróżniającą te dwa wydania była kolejność układu ich stron: na dwóch pierwszych stronach wydania $\mathrm{z}$ roku 1880 zostały umieszczone strony oznaczone w edycji Kingsborougha numerami 44 i 45; z kolei w wydaniu z roku 1892 zostało to już poprawione i widnieją strony oznaczone w edycji Kingsborougha numerami 1 i 2. Pomyłka ta mogła wynikać z niedostatecznej jeszcze wiedzy dotyczącej funkcjonowania kodeksów majańskich oraz nieznajomości majańskiego systemu pisma ${ }^{17}$.

W roku 1933 ukazało się wydanie Kodeksu Drezdeńskiego pod tytułem „Códices Mayas: Dresdensis, Peresianus, Tro-Cortesianus” autorstwa Antonio Villacorta i Carlosa Villacorta. Dokonali oni przerysów omawianego dokumentu, bazując na drugim wydaniu Förstemanna ${ }^{18}$. Kodeks Drezdeński, razem $z$ pozostałymi dwoma manuskryptami majańskimi, został opublikowany w wersji monochromatycznej (czarno-białej). To pierwsza edycja, której duży nakład wydawniczy i jej późniejsze wznowienia przyczyniły się do upowszechnienia tego przykładu kultury piśmienniczej dawnych Majów. Niestety publikacja ta nie jest pozbawiona błędów merytorycznych.

Warto zwrócić uwagę również na edycję Kodeksu Drezdeńskiego autorstwa Helmuta Deckerta oraz Ferdinanda Andersa, która została opublikowana w 1975 roku. Towarzyszy jej bowiem obszerna i wnikliwa analiza kodykolo-

${ }^{15}$ S. Salgado Ruelas, Análisis semiótico..., s. 53; E. Thompson, Códice de Dresde, s. 45.

${ }^{16}$ To technika, którą stosowano dawniej, aby uzyskać wielobarwny druk litograficzny.

${ }^{17}$ Wydanie E. Förstemanna z roku 1892 jest zamieszczone w Internecie, podobnie jak inne, wcześniejsze edycje Kodeksu Drezdeńskiego.

${ }^{18}$ E. Thompson, Códice de Dresde, s. 45. 
giczna pióra Ferdinanda Andersa. To wydanie świetnie uzupełniało publikację Erica Thompsona z roku 1972, która stała się sztandarową pozycją omawiającą szczegółowo zawartość Kodeksu Drezdeńskiego ${ }^{19}$. Do tej książki dołączono faksymile, które miało formę rozwijanej harmonijki (leporello), nawiązując tym samym do oryginalnego układu stron w kodeksach majańskich (wcześniej tylko wydanie Williama Gatesa z roku 1932 uwzględniło taką formę).

Momentem przełomowym w historii edycji Kodeksu Drezdeńskiego stały się fotografie w wysokiej rozdzielczości, udostępnione na oficjalnej stronie internetowej Sächsische Landesbibliothek - Staats- und Universitätsbibliothek Dresden (SLUB). W znacznym stopniu ułatwiają one analizę wielu szczegółów manuskryptu, co wcześniej było utrudnione. Co więcej, internetowa publikacja istotnie poszerza grono odbiorców, którzy mogą podziwiać to szczytowe osiągnięcie kultury piśmienniczej dawnych Majów ${ }^{20}$.

W trakcie badań nad Kodeksem Drezdeńskim należy korzystać jednocześnie z kilku różnych edycji manuskryptu i je porównywać. Umożliwia to zidentyfikowanie detali, które nie zostały uwzględnione w poszczególnych reprodukcjach dokumentu, czy to z powodu błędnej interpretacji, czy to powstających uszkodzeń. Ułatwia to wykrycie ewentualnych nieścisłości bądź pomyłek.

\section{STRONA PIERWSZA KODEKSU}

Stosunkowo dobry stan zachowania Kodeksu Drezdeńskiego sprawił, że stał się on obiektem zainteresowania wielu uczonych. Nie może zatem dziwić ogrom literatury przedmiotu, jaki jest owocem pracy kolejnych pokoleń badaczy. Ten dorobek naukowy zasadniczo koncentruje się wokół trzech kluczowych tematów: astronomiii ${ }^{21}$, ikonografii ${ }^{22}$ oraz lingwistyki ${ }^{23}$. Wachlarz

\footnotetext{
${ }^{19}$ Pierwszy obszerny komentarz do Kodeksu Drezdeńskiego został napisany przez E. Förstemanna w roku $1901 \mathrm{w}$ języku niemieckim. W roku 1906 ukazało się tłumaczenie na język angielski w przekładzie S. Wesselhoeft i A.M. Parker.

${ }^{20}$ Codex Dresdensis [online]. Staats- und Universitätsbibliothek Dresden [dostęp: 2016-12-22]. Dostępny w Internecie: <http://www.slub-dresden.de/sammlungen/handschriften/maya-handschriftcodex-dresdensis/>.

${ }^{21}$ Do tej grupy literatury przedmiotu można zaliczyć takie prace, jak: A. Aveni, Skywatchers: A Revised and Updated Version of Skywatchers of Ancient Mexico, Austin 2001; H.M. Bricker, V. Bricker, Astronomy in the Maya Codices, Philadelphia 2011; Ch. Hernandez, G. Vail, Recreating Primordial Time, Boulder 2013.

${ }^{22}$ Zob. np.: K. Taube, The Major Gods of Ancient Yucatan, Dumbarton Oaks, 1992; M. Paxton, Codex Dresden: Stylistic and Iconographic Analysis of a Maya Manuscript, praca doktorska, Albuquerque 1986.
} 
poruszanych zagadnień szczegółowych jest niezmiernie szeroki: począwszy od wierzeń dawnych Majów poprzez funkcjonowanie systemu kalendarzowego i tablic astronomicznych dotyczących Wenus i zaćmień Słońca, a skończywszy na badaniu zapożyczeń językowych występujących w manuskrypcie.

W tej obszernej literaturze przedmiotu znalazły się jedynie nieliczne publikacje analizujące, i to w sposób lakoniczny, pierwszą stronę Kodeksu Drezdeńskiego (il. 1) ${ }^{24}$. Wynika to $\mathrm{z}$ bardzo złego stanu zachowania tego fragmentu, na którym widoczne są tylko zamazane i niewyraźne kontury, które niegdyś nadawały sens almanachom. Pozostałości tych linii pozwalają jednak stwierdzić, że strona pierwsza została podzielona na trzy części, z czego górna zawiera nietypowe dla sztuki dawnych Majów przedstawienie frontalne twarzy. Środkowy fragment jest tak zniszczony, że nie pozwala obecnie na identyfikację trzech postaci, z których zachowały się tylko niewyraźne zarysy sylwetek. Najlepiej widoczną częścią pierwszej strony jest dolny almanach (1c), na którym można zidentyfikować jedną $\mathrm{z}$ dwóch występujących $\mathrm{w}$ tym miejscu postaci - boga Itzamnah (boga D, według klasyfikacji Schellhasa) ${ }^{25}$.

\section{ALMANACH 1C}

Niedawno została przedstawiona całościowa rekonstrukcja almanachu 1c, która wydobyła na światło dzienne domniemaną zawartość tego pomijanego fragmentu Kodeksu Drezdeńskiego. Stało się to możliwe dzięki analizie porównawczej almanachu znajdującego się w dolnej części drugiej strony manuskryptu (2d). Wykryto wiele analogii między nimi, jak chociażby zastosowanie tego samego układu kompozycji ikonograficznej (postać siedząca - postać w ruchu), powtarzające się struktury gramatyczne czy specyficzny sposób malowania stopy odseparowanej od reszty ciała (il. 2, 3, 4, 5). Zdefiniowanie tych cech pozwoliło na przypisanie autorstwa tych dwóch almanachów jednemu skrybie, co podważa dotychczasowe ustalenia badaczy odnośnie do liczby skrybów biorących udział w tworzeniu Kodeksu Drezdeńskiego ${ }^{26}$. Jed-

${ }^{23}$ Zob. np.: G. Whittaker, The Mexican names of three Venus gods in the Dresden Codex, Mexicon 8, 1986, s. 56-60; R. Wald, The Languages of the Dresden Codex, [w:] S. Wichmann, The Linguistics of Maya Writing, Salt Lake City 2004, s. 27-58.

${ }^{24}$ Zob. np.: E. Thompson, Códice de Dresde..., s. 81; N. Grube, Der Dresdner Maya-Kalender, s. 70; E. Förstemann, Commentary on the Maya Manuscript in the Royal Public Library of Dresden, Cambridge 1906, s. 55; E. Velásquez, Códice de Dresde, Arqueología Mexicana 67, 2016, s. 14.

${ }^{25}$ E. Förstemann, Commentary on the Maya Manuscript, s. 55.

${ }^{26}$ Por.: G. Zimmerman, Die Hieroglyphen der Maya-Handschriften, Tafel 5, Hamburg 1956; N. Grube, Der Dresdner Maya-Kalender..., s. 33; E. Velásquez García, Códice de Dresde, s. 13. 
nakże największą niespodzianką podczas prowadzonych przeze mnie badań była identyfikacja przedmiotu trzymanego przez postaci $\mathrm{z}$ almanachu $1 \mathrm{c}$ jako opaski na biodra (hiszp. braguero, taparrabo). Wynika to $\mathrm{z}$ faktu, że do tej pory nie natrafiono $\mathrm{w}$ zachowanych tekstach glificznych na majański odpowiednik tego słowa ${ }^{27}$.

Dzięki rekonstrukcji tekstu $\mathrm{w}$ omawianym fragmencie manuskryptu wiadomo, że termin najprawdopodobniej określający opaskę na biodra występował w dwóch miejscach, a mianowicie w blokach glificznych B1 i D1. Niestety wśród wszystkich dostępnych edycji Kodeksu Drezdeńskiego tylko w publikacji Förstemanna z roku 1892 zachował się blok glificzny B1 (il. 6). Nawet fotografie $\mathrm{w}$ wysokiej rozdzielczości, udostępnione przez SLUB (Sächsische Landesbibliothek - Staats- und Universitätsbibliothek), nie dostarczają $w$ tym zakresie żadnych informacji, ponieważ ten fragment już w momencie wykonywania rzeczonych zdjęć był całkowicie zniszczony.

Mimo słabo zachowanych konturów glifów bloku B1 można z całą pewnością stwierdzić, iż zostały tam namalowane dwa znaki glificzne ${ }^{28}$. Pierwszy $\mathrm{z}$ nich składa się z dwóch stycznych ze sobą okręgów, a górny fragment zwieńczony jest falistą linią. Drugi element zachował się w znacznie lepszym stanie i kształtem przypomina głowę zoo- bądź antropomorficzną. W prawej dolnej jego części widać okrąg z zaznaczoną wewnątrz kropką. Z tego miejsca wychodzi prosta linia prowadząca do półokręgu. Niewykluczone, że ten fragment przedstawia małżowinę uszną. W tym punkcie linia konturowa opada i nagle się urywa. Jej kontynuacja jest widoczna trochę dalej i przybiera formę litery L, z której później wychodzi kolejna linia, łącząca ją z okręgiem w prawej dolnej części glifu. Można również zaobserwować inną, zewnętrzną linię wychodzącą z wcześniej omówionego fragmentu w formie litery L. Wewnątrz znajdują się elementy przypominające kształtem oko. Wydaje się, że cechy opisujące drugi glif mogą odpowiadać znanym już wariantom glifów przedstawiających głowy nietoperzy, zebranych przez Erika Boota ${ }^{29}$.

Poniżej przedstawiono kilka możliwych kombinacji zapisu glificznego słowa, którego najprawdopodobniej używano na określenie opaski na biodra (hiszp. braguero, taparrabo). Wszystkie podane warianty mają charakter wy-

\footnotetext{
${ }^{27} \mathrm{~K}$. Jagodziński, Los escribas del Códice de Dresde. Un análisis de las páginas 1-2 (w druku).

${ }^{28}$ Przy założeniu, że $\mathrm{w}$ tym bloku glificznym nie zachodzi tzw. konflacja, czyli połączenie dwóch albo i więcej znaków w jeden. Stan zachowania tego fragmentu Kodeksu Drezdeńskiego uniemożliwia jednoznaczne rozstrzygnięcie tej kwestii.

${ }^{29}$ E. Boot, The Bat Sign in Maya Hieroglyphic Writing: Some Notes and Suggestions, Based on Examples on Late Classic Ceramics [online]. Maya Vase Data Base [dostęp: 2016-12-20]. Dostępny w Internecie: <http://www.mayavase.com/boot_bat.pdf $>$.
} 
łącznie roboczy, gdyż przedstawiono słabe i mocne strony proponowanych odczytów, wymagających dalszych, intensywnych badań zarówno epigraficznych, jak i lingwistycznych.

Wcześniejsze badania manuskryptów z okresu postklasycznego (Kodeksów: Madryckiego i Drezdeńskiego) wykazały, że są to dokumenty dwujęzyczne, gdyż można w nich odnaleźć słowa pochodzące z klasycznego majańskiego (z grupu cholańskiej) oraz grupy jukateckiej (jukatecki/itza-mopan) ${ }^{30}$. W tabeli nr 1 zebrano wszystkie formy majańskiego słowa określającego opaskę na biodra, uwzględniając tylko języki z grupy cholańskiej i jukateckiej ${ }^{31}$. W zależności od afiliacji językowej termin ten może przybierać następującą formę: weex, wex, eex lub ex.

Tab. 1. Określenie „opaska na biodra” w różnych językach majańskich

\begin{tabular}{|l|l|}
\hline \multicolumn{1}{|c|}{ Język majański } & \multicolumn{1}{|c|}{ Wyraz „opaska na biodra” } \\
\hline protomajański (pM) & weex \\
\hline jukatecki (YUK) & eex \\
\hline itza (ITZ) & wex \\
\hline mopan (MOP) & wex \\
\hline proto-cholański (pCh) & wex \\
\hline ch'orti' (CHR) & ex \\
\hline ch'orti' (CHR) & ex \\
\hline ch'orti' (CHR) & ex \\
\hline ch'olti' (CHT) & wex \\
\hline ch'ol (CHL) & wex \\
\hline tzotzil (TZO) & wex \\
\hline tzeltal (TZE) & wex \\
\hline chontal (YOK) & wex \\
\hline
\end{tabular}

Źródło: Opracowanie własne na podstawie „A Preliminary Mayan Etymological Dictionary” T. Kaufmana i J. Justesona oraz słownika „Diccionario Chontal de Tabasco” autorstwa K. Keller i G. Luciano.

Przed przystąpieniem do omówienia możliwych form zapisu tego terminu należy przyjąć kilka wstępnych założeń. Po pierwsze, w omawianym bloku glificznym nie występuje konflacja. Po drugie, wyraz wex, eex lub ex musi być

\footnotetext{
${ }^{30}$ A. Lacadena, Bilingüismo en el Códice de Madrid, Los investigadores de la Cultura Maya 5, 1997, s. 184-204; R. Wald, The Languages of the Dresden Codex. Legacy of the Classic Maya, [w:] S. Wichmann, The Linguistics of Maya Writing, Salt Lake City 2004, s. 27-58; A. Davletshin 2016, informacja własna.

${ }^{31}$ Opracowanie własne na podstawie „A Preliminary Mayan Etymological Dictionary” T. Kaufmana i J. Justesona oraz słownika „Diccionario Chontal de Tabasco” autorstwa K. Keller i G. Luciano.
} 
zapisany dwoma glifami, co jest konsekwencją rozmieszczenia graficznego bloku B1. Po trzecie, słowo powinno pojawić się w formie dzierżawczej, analogicznie do swojego odpowiednika w almanachu 2d. Mając na uwadze wyżej wymienione założenia oraz reguły ${ }^{32}$, jakie rządzą systemem pisma dawnych Majów, możliwe są następujące rozwiązania:

Tab. 2. Możliwe kombinacje zapisu określenia „opaska na biodra”

\begin{tabular}{|l|l|l|}
\hline \multicolumn{1}{|c|}{ I grupa } & \multicolumn{1}{c|}{ II grupa } & \multicolumn{1}{c|}{ III grupa } \\
\hline$u$-we-xe & $w e-x e$ & $y e-x e$ \\
\hline$u$-we- $x i$ & $w e-x i$ & $y e-x i$ \\
\hline$u$-WEX-xe & $u$-WEX & $y e-E X$ \\
\hline$y e-E X-x e$ & $W E X-x e$ & $E X-x e$ \\
\hline$y e-E X-x i$ & $W E X-x i$ & $E X-x i$ \\
\hline
\end{tabular}

Źrodło: opracowanie własne na podstawie literatury podanej w bibliografii załączonej do artykułu.

W tabeli 2 zebrano wszystkie potencjalne zapisy analizowanego słowa. Przede wszystkim należy odrzucić wszelkie proponowane odczyty z pierwszej kolumny (I grupa), ponieważ wymagałyby użycia aż trzech osobnych znaków glificznych, a namalowano tylko dwa, chociaż jest miejsce na trzeci glif. To miejsce jest wystarczająco obszerne dla umieszczenia sylaby $u$, ale niewystarczające $\mathrm{w}$ przypadku sylaby y $e^{33}$. Wydaje się uzasadnione odrzucenie również wersji zapisu $u$ - $W E X^{34} \mathrm{z}$ II grupy tabeli 2 . Kształt znaku glificznego w tekście, który odpowiada pozycji sylaby $u^{35}$, przy takim zapisie odbiega od typowego glifu odpowiadającego samogłosce $u$ dla porównywanych almanachów 1c i $2 \mathrm{~d}$. Wszystkie inne bowiem formy sylaby $u \mathrm{w}$ almanachach $1 \mathrm{c}$ i $2 \mathrm{~d}$, które są wyraźnie dziełem tego samego skryby, przybierają zupełnie inny kształt ogólny. Na 16 bloków glificznych zawartych w almanachach 1c i 2d twórca używa bowiem aż siedem razy sylaby $u$, umieszczając ją zawsze przed każdą formą czasownikowąa ${ }^{36}$ i przed każdym rzeczownikiem w almanachu $2 \mathrm{~d}^{37}$, zawsze

\footnotetext{
${ }^{32}$ Ch. Helmke, H. Kettunen, Wprowadzenie do hieroglifów Majów..., s. 14-37.

${ }^{33}$ Dodatkową komplikacją jest fakt, iż puste, wąskie miejsce znajduje się po prawej stronie analizowanego rzeczownika, a nie po jego lewej, jak to bywa w przypadku stosowania zaimka dzierżawczego w klasycznym języku majańskim.

${ }^{34}$ Zgodnie z obowiązującymi zasadami w epigrafice Majów transliteracja zapisywana jest pogrubioną czcionką, a logogramy pisane są zawsze dużymi literami; z kolei w transkrypcji stosuje się kursywę i wszystkie elementy zapisywane są zawsze małymi literami.

${ }^{35}$ Zaznacza w tym przypadku formę dzierżawczą trzeciej osoby liczby pojedynczej.

${ }^{36} \mathrm{~W}$ tym przypadku określa podmiot wykonywanej czynności w trzeciej osobie liczby pojedynczej strony czynnej.

${ }^{37}$ Brak danych odnośnie do rzeczowników w almanachu 1c.
} 
w podobnej, powtarzającej się formie. $\mathrm{Z}$ tej racji jest bardzo mało prawdopodobne, aby $\mathrm{w}$ tym jedynym przypadku nastąpiła tak znacząca zmiana $\mathrm{w}$ sposobie przedstawiania danego glifu przez tego skrybę. Pozostałe zapisy z drugiej kolumny tabeli 2 nie spełniają warunku użycia formy dzierżawczej. W gramatyce klasycznego języka majańskiego istnieje zasada, że przed każdym rzeczownikiem $\mathrm{w}$ formie dzierżawczej, rozpoczynającym się od spółgłoski, musi pojawić się sylaba $u$. W bloku glificznym B1 jest wystarczająco dużo miejsca na jej namalowanie, tym bardziej że stosowany wariant nie ma dużego rozmiaru. Dwa ostatnie warianty z grupy II tabeli $2 W E X$-xe i $W E X$ - $x i$ należy zatem odrzucić ze względu na konsekwentne stosowanie zaimków dzierżawczych przez twórcę omawianego zespołu almanachów 1c i $2 \mathrm{~d}$. W bloku glificznym B1 jest wystarczająco przestrzeni, aby ją namalować, tym bardziej że stosowany przez tego pisarza wariant nie zajmuje sporo miejsca. Brak zastosowania takich zaimków właściwie wyklucza autorstwo skryby $\mathrm{z}$ almanachu $2 \mathrm{~d} \mathrm{w}$ odniesieniu do almanchu $1 \mathrm{c}$ w przypadku takiej formy zapisu słowa, przy założeniu, że majański termin braguero zaczyna się od spółgłoski $w^{38}$.

Warto też zaznaczyć, że ostatnio opublikowano artykuł dotyczący odszyfrowania sylaby $w e^{39}$, co jest kolejnym znaczącym wkładem w proces odczytywania pisma Majów. Puste miejsca w majańskim sylabariuszu powoli zostają wypełniane konkretnymi glifami. Zaprezentowane przez autorów wskazanej publikacji warianty tej sylaby różnią się w pewnym znaczącym szczególe przy porównaniu z pierwszym znakiem glificznym $\mathrm{w}$ zapisie we-xe i we-xi z grupy II tabeli $2^{40}$. Nie można jednak kategorycznie wykluczyć i takiej sytuacji, $\mathrm{w}$ której mamy do czynienia $\mathrm{z}$ nowym wariantem sylaby we $\mathrm{w}$ omawianym przypadku bloku glificznego B1.

Szczególnej analizy wymagają zapisy z III grupy tabeli 2. Najmniej prawdopodobną kombinacją $\mathrm{z}$ trzeciej kolumny jest wersja ye-EX. Spełnia ona wcześniej postawione założenia, jednakże sam glif ye, który występuje

\footnotetext{
${ }^{38}$ Nie można całkowicie i kategorycznie wykluczyć sytuacji, w której skryba pominął świadomie sylabę $u$, kierując się nieznanymi w chwili obecnej powodami, np. względami estetycznymi. Wydaje się to jednak mało prawdopodobne.

${ }^{39}$ M. Zender i in., The Syllabic Sign we and an Apologia for Delayed Decipherment, PARI Journal 17, 2, 2016, s. 35-56.

${ }^{40}$ Ze względu na mocno zerodowany blok glificzny B1 nie można dziś jednoznacznie stwierdzić, czy ów znak można utożsamiać $\mathrm{z}$ nowo zidentyfikowaną sylabę we w omawianym artykule, mimo ich podobnego kształtu. Wątpliwości co do poprawności takiej identyfikacji nasuwają się, ponieważ pojawia się „wąs” w górnej części analizowanego znaku, którego nie ma w zaprezentowanych wariantach sylaby we w artykule Zendera, Beliaeva i Davletshina.
} 
w wielu tekstach glificznych, w niczym nie przypomina kształtem pierwszego znaku z bloku glificznego B1. Logogram określający opaskę na biodra powinien mieć ponadto jakiś związek $\mathrm{z}$ ikonografią, podobnie jak w przypadku logogramu $P I K \mathrm{w}$ almanachu 2d. Ilustruje on kawałek tkanej spódniczki, na zasadzie pars pro toto, znanej z przedstawień z okresu klasycznego. W przypadku bloku B1 znak znajdujący się na drugim miejscu nie wykazuje takich podobieństw.

Dwa początkowe warianty ye-xe oraz ye-xi z III grupy tabeli 2 także należałoby odrzucić ze względu na brak podobieństwa pierwszego glifu do sylaby ye.

Ostatnie dwie propozycje zapisu $E X$-xe i $E X$-xi, mimo że nie spełniają warunku użycia formy dzierżawczej, zasługują na większą uwagę.

W gramatyce klasycznego języka majańskiego istnieje zasada, że przed każdym rzeczownikiem w formie dzierżawczej rozpoczynającym się samogłoską musi się pojawić ergatywny zaimek afiksowy $y V$ - ( $V$ jako oznaczenie samogłoski rdzenia rzeczownikowego, od ang. vowel - samogłoska). Z tego powodu, aby zapisać słowo eex/ex w formie dzierżawczej, należałoby je rozpocząć sylabą ye. Uważna analiza dostępnej przestrzeni bloku glificznego B1 pozwala stwierdzić, że nie ma miejsca na umieszczenie pełnego wyrażenia $y e-E X$-xe bądź $y e-E X$-xi, o czym wspomniano powyżej. Świadomy tego skryba mógł zadecydować, że zamieści tylko skróconą wersję tego związku wyrazowego w postaci $E X$-xe bądź $E X$-xi. Trudno stwierdzić jednoznacznie, która z tych wersji zapisu może być prawidłowa. Warto jednak zauważyć, że sylaba $x i$ występuje już w sylabariuszu i ma zupełnie inną formę (przedstawia czaszkę) niż kształt drugiego znaku w bloku glificznym B1. Oczywiście nie można całkowicie wykluczyć zastosowania przez skrybę nowego wariantu tego zna$\mathrm{ku}$, jednak prawdopodobieństwo tego jest niewielkie. $Z$ kolei sylaba $x e$ jeszcze nie została zidentyfikowana w korpusie tekstów majańskich. Jedyna wzmianka na ten temat pojawia się w słynnym „alfabecie” biskupa Diego de Landy, gdzie zostało zapisane $x(e$ ?), ale nie ma pewności, czy to fonogram $X E$, czy może logogram $X E^{\prime}$, który oznacza „wymiotować, wymiociny”41. Sprawę odszyfrowania zapisu słowa z bloku B1 komplikuje niewątpliwie fakt, że termin ten pojawia się po raz pierwszy w korpusie inskrypcji majańskich. Poza tym elementy składowe tworzone są przez znaki przynajmniej w części dotychczas nieznane. Nieprecyzyjny zapis w „alfabecie” Landy stanowi interesującą wskazówkę dla dalszych badań epigraficznych.

\footnotetext{
${ }^{41}$ A. Lacadena, informacja własna, 2016; B. Tuszyńskia, informacja własna, 2016.
} 


\section{PODSUMOWANIE}

Kodeks Drezdeński to niezwykle cenne źródło do badań nad dawną kulturą Majów. Dobitnie o tym świadczą żywe zainteresowanie naukowców oraz liczba prac publikowanych na jego temat. Można jednak zauważyć pewien dysonans w traktowaniu poszczególnych stron tego manuskryptu. Dotychczas główna uwaga skupiała się na tych fragmentach, które zachowały się $\mathrm{w}$ dobrym lub bardzo dobrym stanie. $Z$ kolei strona pierwsza, najbardziej ze wszystkich dotknięta upływem czasu, nie przykuwała uwagi zbyt wielu badaczy. Proponowana rekonstrukcja almanachu 1c prowadzi do odtworzenia słowa dotychczas niewystępującego w korpusie majańskich tekstów. Co więcej, jego analiza może przyczynić się do zgłębienia funkcjonowania systemu pisma dawnych Majów. Zaproponowane tutaj teoretyczne modele odszyfrowania słowa określającego opaskę na biodra nie mają charakteru definitywnego, są asumptem do podjęcia bardziej wnikliwych analiz epigraficznych i lingwistycznych. Niezwykle przydatne byłoby wykorzystanie najnowszych osiągnięć techniki fotograficznej do wykonania nowych zdjęć stron Kodeksu Drezdeńskiego. Pozwoliłoby to na bardziej skrupulatne prześledzenie tego, jak na zachowanych fragmentach przebiegają linie niewidoczne gołym okiem.

\section{PODZIĘKOWANIA}

Autor chciałby wyrazić swoją wdzięczność Alfonso Lacadenie García-Gallo, Boguchwale Tuszyńskiej, Kamilowi Jagodzińskiemu, Albertowi Davletshinowi, Elizabeth Wagner oraz dwóm anonimowym recenzentom za cenne komentarze i uwagi dotyczące opisywanej materii. Specjalne podziękowania należą się Marii Soler Gómez za przygotowanie ilustracji (il. 4 i 5) oraz Los Angeles County Museum of Art (LACMA) za udzielenie zgody na publikacje ilustracji (il. 1, 2, 3 i 6) pochodzących z wydania Kodeksu Drezdeńskiego autorstwa Ernsta Förstemanna z 1892 r. 


\section{Kajetan Jagodziński \\ SIGNIFICANCE OF THE ALMANAC 1C OF THE DRESDEN CODEX FOR THE DEVELOPMENT OF MAYAN EPIGRAPHY}

\section{Summary}

Comparative analysis of almanacs found on page two (2d) and one (1c) made it possible to reconstruct the content of the latter which, due to poor state of preservation, has not been an object of any thoroughgoing analyses. Conducted research yielded highly interesting findings, revealing a term denoting a loincloth (braguero or taparrabo in Spanish). However, the glyphs in the almanac 1c are substantially damaged, therefore conclusive interpretation is impossible at present. The factor which makes the issue even more complicated is the fact that Mayan term wex/eex/ex can consist of syllables or logograms, which are either rare or altogether absent in the Mayan corpus of glyphic texts. Suggested variants of the word as it would appear in script require further epigraphic and linguistic studies. 


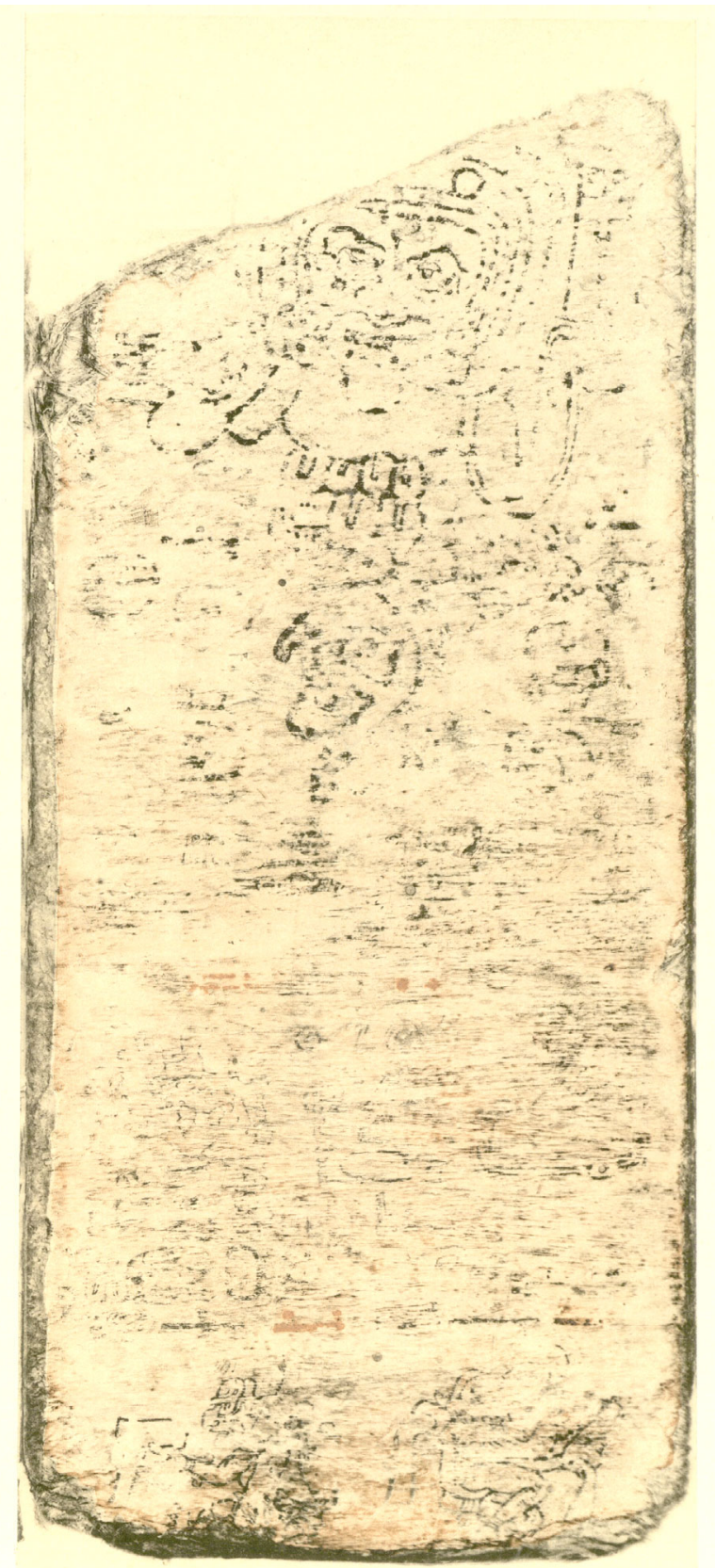

Il. 1. Strona 1 Kodeksu Drezdeńskiego, wydanie E. Förstemanna z 1892 r., dzięki uprzejmości Ancient Americas z LACMA 


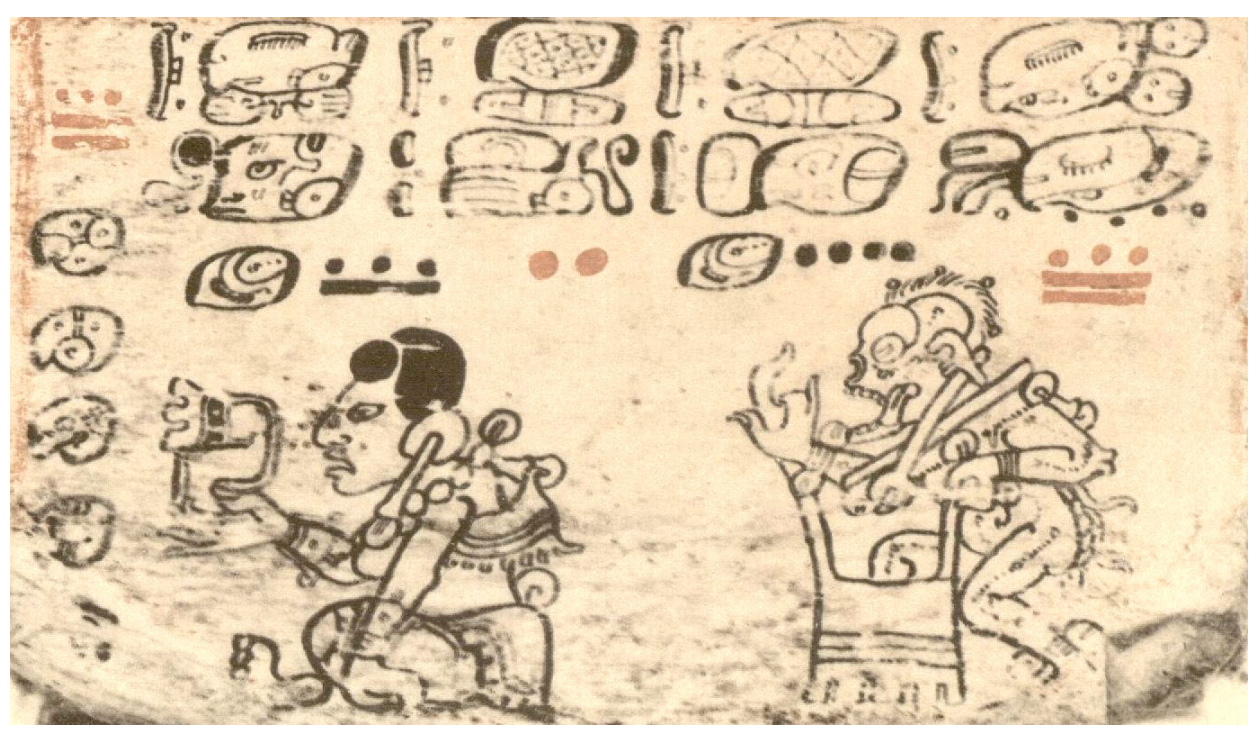

Il. 2. Almanach ze strony 2 (2d), wydanie E. Förstemanna z 1892 r., dzięki uprzejmości Ancient Americas z LACMA

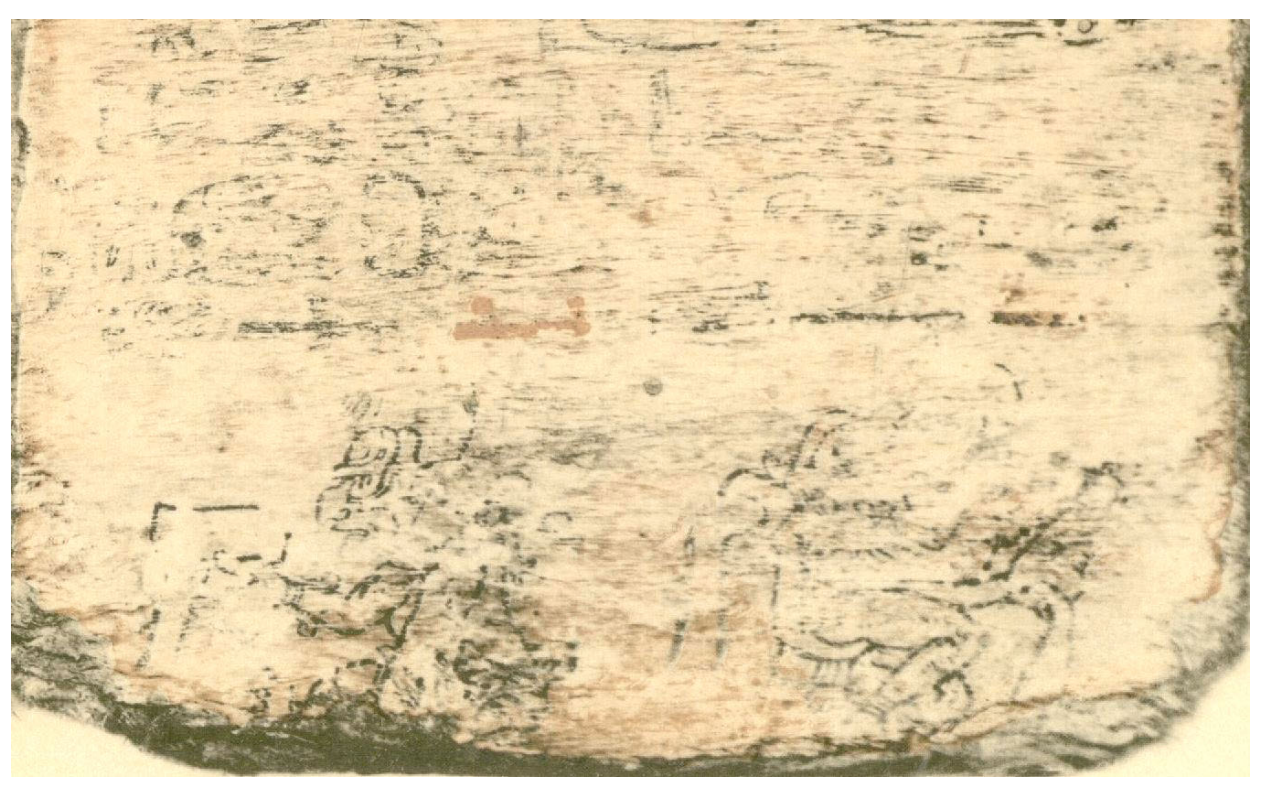

Il. 3. Almanach ze strony 1 (1c), wydanie E. Förstemanna z 1892 r., dzięki uprzejmości Ancient Americas z LACMA 


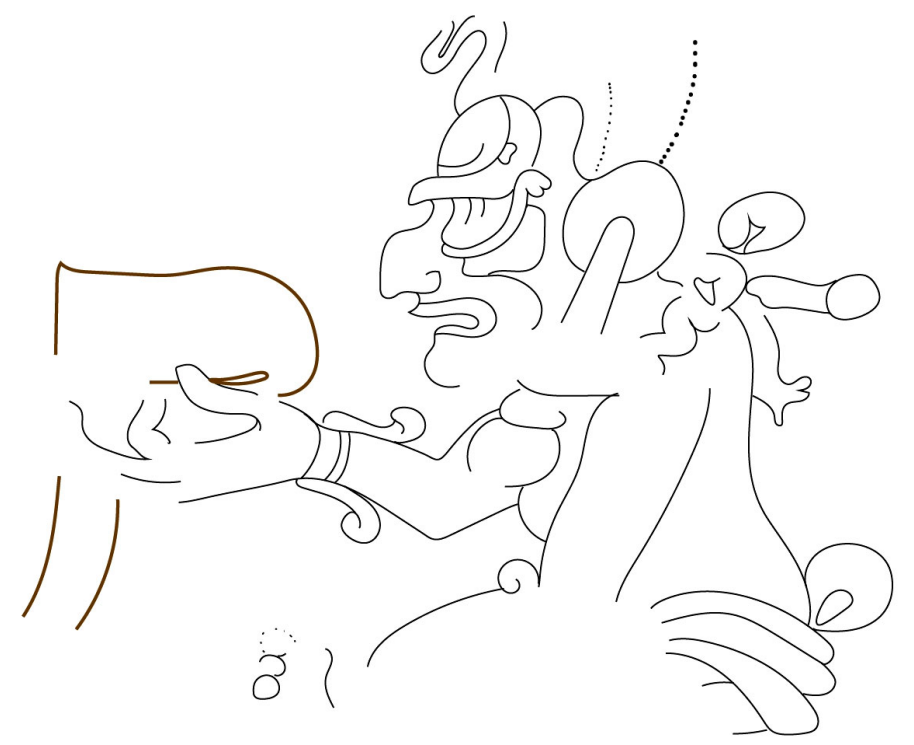

Il. 4. Pierwsza postać z almanachu 1c, autor: María Soler Gómez

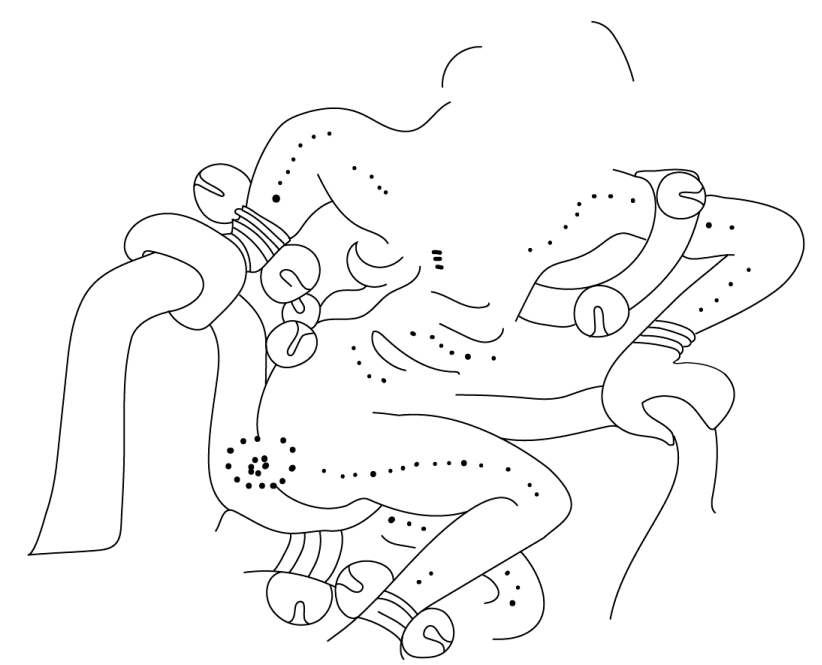

Il. 5. Druga postać z almanachu 1c, autor: María Soler Gómez 


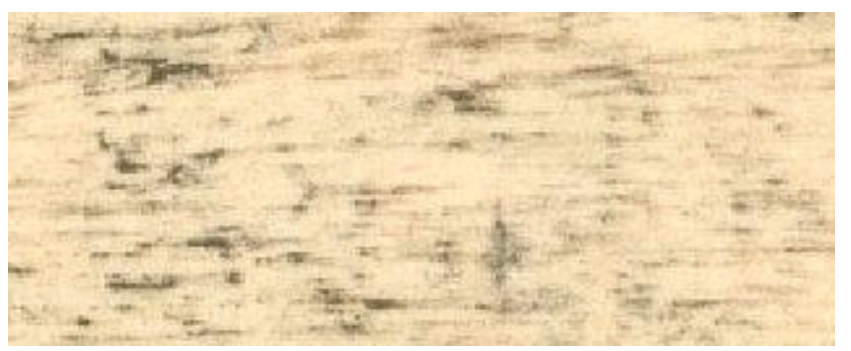

Il. 6. Blok glificzny B1 z almanachu 1c, wydanie E. Förstemanna z 1892 r., dzięki uprzejmości Ancient Americas z LACMA

\section{Bibliografia}

Anders F., Deckert H., Codex Dresdensis, Graz 1975.

Aveni A., Skywatchers: A Revised and Updated Version of Skywatchers of Ancient Mexico, Austin 2001.

Boot E., The Bat Sign in Maya Hieroglyphic Writing: Some Notes and Suggestions, Based on Examples on Late Classic Ceramics [online]. Maya Vase Data Base [dostęp: 2016-12-20]. Dostępny w Internecie: <http://www.mayavase.com/boot_bat.pdf $>$.

Bricker H.M., Bricker V., Astronomy in the Maya Codices, Philadelphia 2011.

Bricker H.M., Bricker V., A method for cross-dating almanacs with tables in the Dresden Codex, [w:] A.F. Aveni (red.), The Sky in Mayan Literature, New York 1992, s. 46-87.

Chuchiak IV J.F., Writing as Resistance: Maya Graphic Pluralism and Indigenous Elite Strategies for Survival in Colonial Yucatan, 1550-1750, Ethnohistory 57, 2010, s. 87-116.

Coe M. et al., The Fourth Maya Codex, [w:] Ch. Gordon et al. (red.), Maya Archaeology 3, 2016, s. 116-167.

Coe M., Una referencia antigua al Códice de Dresde, Estudios de Cultura Maya 3, 1963, s. 37-40.

Förstemann E., Commentary on the Maya Manuscript in the Royal Public Library of Dresden, Cambridge 1906.

Förstemann E., Codex Dresdensis [online]. FAMSI [dostęp: 2016-12-20]. Dostępny w Internecie: $<$ http://www.famsi.org/mayawriting/codices/pdf/1_dresden_fors_schele_pp01-12.pdf $>$.

Grube N., Der Dresdner Maya-Kalender: Der vollständige Codex, Freiburg-Bassel-Wien 2012.

Helmke Ch., Kettunen H., Wprowadzenie do Hieroglifów Majów [online]. Wayweb [dostęp: 2016-12-20]. Dostępny w Internecie: <http://www.wayeb.org/download/resources/wh2009 polish.pdf>.

Hernandez Ch., Vail G., Recreating Primordial Time. Foundation Rituals and Mythology in the Postclassic Maya Codices, Boulder 2013.

Jagodziński K., Los escribas del Códice de Dresde. Un análisis de las páginas 1-2 (w druku).

Kaufman T., Justeson J., A Preliminary Mayan Etymological Dictionary [online]. FAMSI [dostęp: 2016-12-20]. Dostępny w Internecie: <http://www.famsi.org/reports/01051/>.

Keller K., Luciano G., Diccionario Chontal de Tabasco, Tucson 1997.

Lacadena A., Evolución formal de las grafías escriturarias mayas: Implicaciones históricas y culturales, Madrid 1995.

Lacadena A., Bilingüismo en el Códice de Madrid, Los investigadores de la Cultura Maya 5, 1997, s. 184-204.

Lee T. (red.), Los Códices Mayas, Tuxtla Gutiérrez 1985. 
Paxton M., Codex Dresden: Late Postclassic Ceramic Depictions and the Problems of Provenience and Date of Painting, [w:] V.M. Fields, M.G. Robertson (red.), Sixth Palenque Round Table, 1986, Oklahoma 1991, s. 303-308.

Paxton M., Codex Dresden: Stylistic and Iconographic Analysis of a Maya Manuscript, praca doktorska, Albuquerque 1986.

Salgado Ruelas S., Análisis semiótico de la forma arbórea en el Códice de Dresde, Mexico 2001.

Taube K., The Major Gods of Ancient Yucatan, Dumbarton Oaks 1992.

Thompson E., Códice de Dresde. Un comentario al Códice de Dresde. Libro de jeroglifos mayas, México 1988.

Velásquez E., Códice de Dresde, Arqueología Mexicana 67, 2016, s. 14.

Wald R., The Languages of the Dresden Codex, [w:] S. Wichmann (red.), The Linguistics of Maya Writing, Salt Lake City 2004, s. 27-58.

Whittaker G., The Mexican names of three Venus gods in the Dresden Codex, Mexicon 8, 1986, s. 56-60.

Zender M. et al., The Syllabic Sign we and an Apologia for Delayed Decipherment, Pari Journal $17,2,2016$, s. 35-56.

Zimmerman G., Die Hieroglyphen der Maya-Handschriften, Hamburg 1956.

Codex Dresdensis [online]. Staats- und Universitätsbibliothek Dresden [dostęp: 2016-12-22]. Dostępny w Internecie: <http://www.slub-dresden.de/sammlungen/handschriften/mayahandschrift-codex-dresdensis/ $>$. 
